\title{
Progress of Competence Development in Bacillus subtilis
}

\author{
By R. N.SINGH AND M. P. PITALE \\ Molecular Biology Unit, Tata Institute of Fundamental Research, \\ Homi Bhabha Road, Bombay 400005 , India
}

(Received 2I March 1973; revised 28 January' 1974)

SUMMAR Y

B. subtilis can develop the capacity to take up transforming DNA and at the same time continue to grow for about $I_{2} \frac{1}{2}$ to $3 \mathrm{~h}$. Such growing competent cells are susceptible to penicillin. The competent cells, if allowed further growth, eventually become penicillin insensitive.

\section{INTRODUCTION}

When competent cultures of Bacillus subtilis were transformed with DNA and exposed to penicillin the transformants were relatively resistant to the antibiotic (Nester, 1964; Nester \& Stocker, 1963). The competent cells in these experiments were in a state of biosynthetic latency evidenced by lack of cell division and a delay in the synthesis of enzymes specified by the donor genes (Nester \& Stocker, 1963). It was inferred that the resistance of transformants to the bactericidal action of penicillin was due to the fact that the competent cells are non-growing (Hobby, Meyer \& Chaffee, 1942, cited in Nester, 1964; Nester \& Stocker, 1963; Stocker, 1963). The earlier investigators used the nutritional step-down procedure of Anagnostopoulos \& Spizizen (1961) for inducing competence. Under these conditions, immediately before shifting to the transformation medium (Young \& Spizizen, 1961) the cells are on the verge of entering into stationary phase. Tomasz (1969) pointed out that the bactericidal action of penicillin should preferably be studied in logarithmically growing cultures which can be made competent by the spore-germination method of Ephrati-Elizur ( 1965 ). We have investigated the action of penicillin on competent cultures which had not entered the stationary phase and have also repeated the experiments using the nutritional step-down procedure for competence development. The results show that the competent cells are initially sensitive to penicillin.

\section{METHODS}

Strains. Bacillus subtilis strains $168 \mathrm{trpC2}$ and $\mathrm{I} 68-2 \operatorname{trpC2}$ leu-2 were used as recipients. B. subtilis 168 met-II obtained by ultraviolet irradiation of the prototrophic strain 168 and B. subtilis GSY 568 ade ura thy $X$ thy $Y I$ were used as donors.

Chemicals. Lysozyme (Sigma), Sarkosyl NL-97 (Geigy), pronase B (Calbiochem), deoxyribonuclease-I (DNase; Worthington), penicillin G ('Crystapen', sodium benzyl penicillin, injectable, Glaxo) and penicillinase ('Neutrapen', injectable, Serva) were used. The solutions of penicillin were prepared freshly at concentrations 40000 or 4000 i.u. penicillin/ml.

DNA. DNA was isolated from B. subtilis I 68 met-II according to Marmur (I96I). DNA from the strain GSY 568 ade ura thy $X$ thy $Y_{I}$ was isolated by using Sarkosyl-pronase treatment 
according to Siddiqi \& Fox (1973). The DNA concentration in solutions was determined spectrophotometrically at $260 \mathrm{~nm}$ taking the extinction unit/cm equivalent to $47 \mu \mathrm{g} \mathrm{DNA} / \mathrm{ml}$ (Ganesan \& Lederberg, I964).

Preparation of spores. The strain $\operatorname{trpC2}$ was grown at $37^{\circ} \mathrm{C}$ first in tryptone broth for $5 \mathrm{~h}$ and then in minimal medium (Spizizen, 1958 ) devoid of nitrogen and glucose for $90 \mathrm{~h}$. More than $90 \%$ of the cells were converted to spores. The spores were washed and resuspended in physiological saline $(\mathrm{pH} 7)$, heated for $\mathrm{I} 0$ min at $80{ }^{\circ} \mathrm{C}$ and stored at approx. $5{ }^{\circ} \mathrm{C}$. The titre of viable spores was determined by plating on nutrient agar.

Media. Medium A used for inoculating spores contained minimal glucose medium (Spizizen, 1958), supplemented with $(\mu \mathrm{g} / \mathrm{ml})$ : L-tryptophan, I0; adenine, 5; and Casamino acids (Difco), I00. Medium B was minimal glucose medium supplemented with $(\mu \mathrm{g} / \mathrm{ml})$ : L-arginine, 200; L-tryptophan, I0; Casamino acids, I00; and additional 0.00 I-M magnesium sulphate used for the development of competence. Medium $\mathrm{C}$ was minimal glucose medium supplemented with $50 \mu \mathrm{g}$ L-tryptophan $/ \mathrm{ml}$, and $3 \mathrm{mg}$ 'Bacto' yeast extract (Difco) $/ \mathrm{ml}$. Medium D was minimal glucose medium supplemented with $5 \mu \mathrm{g}$ L-tryptophan $/ \mathrm{ml}, \mathrm{Img}$ 'Bacto' yeast extract/ml and additional o.oor M-magnesium sulphate.

Washing or resuspension medium (WR) contained minimal glucose medium plus I $\mu \mathrm{g}$ L-tryptophan and $100 \mu \mathrm{g}$ Casamino acids $/ \mathrm{ml}$.

The experiments at $37^{\circ} \mathrm{C}$ were performed in a thermostatically controlled room, whereas for experiments at $32^{\circ} \mathrm{C}$ a gyratory water bath shaker for flasks and a reciprocating water bath shaker for test tubes were used.

Development of competence. Two different methods of inducing competence were employed:

Method I: Spore germination method of Ephrati-Elizur (1965). About $2.5 \times 10^{7}$ viable spores were inoculated in $\mathrm{I} 0 \mathrm{ml}$ of medium $\mathrm{A}$ and allowed to grow for $\mathrm{I} 8 \mathrm{~h}$ at $37^{\circ} \mathrm{C}$. Five $\mathrm{ml}$ were then diluted in $45 \mathrm{ml}$ medium B in a $500 \mathrm{ml}$ Erlenmeyer flask and grown at $37^{\circ} \mathrm{C}$ on a rotary shaker. The competent cells appeared in the growing culture in medium $\mathrm{B}$, from the beginning.

Method 2: Nutritional step-down procedure of Anagnostopoulos \& Spizizen (I96I) and Nester, Schafer \& Lederberg (1963). About 50 cells of strain $\operatorname{trpC} 2$ or $\operatorname{trpC} 2$ leu-2 were inoculated in $200 \mathrm{ml}$ tryptone broth and grown for $16 \mathrm{~h}$ on a rotary shaker at $37^{\circ} \mathrm{C}$. Fifteen $\mathrm{ml}$ of this culture were centrifuged and the cells suspended in medium $\mathrm{C}$ and grown at $37^{\circ} \mathrm{C}$ on a rotary shaker in a baffled flask. At the end of the logarithmic phase of growth, cells from $2 \mathrm{ml}$ of this culture were centrifuged and resuspended in $18 \mathrm{ml}$ of prewarmed $\left(37^{\circ} \mathrm{C}\right)$ medium D. This culture was slowly shaken at about $25 \mathrm{rev} . / \mathrm{min}$ at $37{ }^{\circ} \mathrm{C}$. The competent cells started appearing immediately after resuspension in medium D.

Penicillin treatment of the culture developing competence. One $\mathrm{ml}$ portions of the competent culture from either method I or method 2 were transferred at o, 30, 60, 90, I20, 240, 300 and $360 \mathrm{~min}$ to two $19 \mathrm{~mm}$ diam tubes. To the first tube $0.05 \mathrm{ml}$ penicillin solution was added and to the second tube $0.05 \mathrm{ml}$ of minimal buffer. Both the tubes were agitated for $\mathrm{I} \mathrm{h}$ at $37{ }^{\circ} \mathrm{C}$. Five $\mu \mathrm{g}$ of $B$. subtilis met-II DNA were then added to each tube and agitation was continued for an additional $30 \mathrm{~min}$. The contents of both the tubes were centrifuged separately. The cells were washed once with $3 \mathrm{ml}$ of WR medium and suspended in I $\mathrm{ml}$ of the same medium. The transformants and viable cells were then assayed.

To confirm that penicillin does not inhibit the uptake of transforming DNA, a control experiment was carried out in which 2000 i.u. penicillin were added to I $\mathrm{ml}$ competent culture of $B$. subtilis $168 \operatorname{trpC2}$, followed by $5 \mu \mathrm{g}$ transforming DNA from the strain met-II $0.5 \mathrm{~min}$ later. To another portion of the same culture DNA was added first and penicillin later. The 
two samples were shaken for $30 \mathrm{~min}$ at $37{ }^{\circ} \mathrm{C}$ then washed and assayed for transformants. The titres of $\mathrm{Trp}^{+}$transformants in the two cultures were $5.4 \times 10^{4} / \mathrm{ml}$ and $5.8 \times 10^{4} / \mathrm{ml}$ respectively.

The effectiveness of washing of penicillin-treated cells free of inhibiting concentrations of penicillin, which might be carried over to agar plates on subsequent spreading on minimal agar, was checked. To one of the two tubes, each containing I ml transformed culture, 2000 i.u. penicillin were added, and to the other tube an equivalent volume of minimal buffer. Both tubes were quickly chilled in an ice-water bath to prevent any killing of the cells in the penicillin-containing culture. Cells from both the tubes, i.e. penicillin-treated and -untreated cells, were washed once and resuspended at approx. $5{ }^{\circ} \mathrm{C}$. The titres of transformants and viable cells in both the cultures were similar.

Penicillin treatment of the culture at $32{ }^{\circ} \mathrm{C}$ using penicillinase for destruction of penicillin and DNase for terminating DNA uptake. In these experiments method 2 was followed for development of competence, but the culture was incubated in medium D at $32{ }^{\circ} \mathrm{C}$ instead of $37^{\circ} \mathrm{C}$. Two $0.10 \mathrm{ml}$ portions of the competent culture were transferred at $0,30,60,90$, $120,150,180$ and 210 min to two tubes containing $0.9 \mathrm{ml}$ medium D at $32{ }^{\circ} \mathrm{C}$. To one tube $0.05 \mathrm{ml}$ penicillin solution containing $200 \mathrm{i}$.u. penicillin was added, and to the other tube an equivalent quantity of penicillin (hydrolysed) pre-degraded by penicillinase, or minimal buffer was added. Both the tubes were incubated for $\mathrm{I} \mathrm{h}$ at $32{ }^{\circ} \mathrm{C}$ with agitation. Then 400 units of penicillinase were added to each tube. After $5 \mathrm{~min}$ further incubation, $5 \mu \mathrm{g}$ B. subtilis GSY568 DNA were added to cultures in each of the tubes. After a contact time of Io min with DNA, further uptake was terminated by 50 to $100 \mu \mathrm{g}$ DNase in the presence of $0.005 \mathrm{M}$-magnesium sulphate.

Assay of transformants and viable cells. Viable cell titre was assayed on nutrient agar and $\mathrm{Trp}^{+}$transformants were assayed on minimal glucose agar supplemented with $200 \mu \mathrm{g}$ Casamino acids (Difco) plus $30 \mu \mathrm{g}$ L-leucine $/ \mathrm{ml}$. Colonies were counted after overnight incubation at $37^{\circ} \mathrm{C}$.

\section{RESULTS}

To study the effect of adding penicillin during the development of competence on transformation in B. subtilis, recipient cells were prepared by germination of spores. At various times, samples of the culture were withdrawn and treated with $2000 \mathrm{i}$.u. penicillin $/ \mathrm{ml}$ for I $\mathrm{h}$ and then exposed to $5 \mu \mathrm{g}$ transforming DNA $/ \mathrm{ml}$ for $30 \mathrm{~min}$ at $37^{\circ} \mathrm{C}$. Figure I shows that initially $85 \%$ or more of the cells were sensitive to penicillin but by $240 \mathrm{~min}$ about $30 \%$ had become refractory to the drug. Competent cells were also initially sensitive to penicillin and gradually developed resistance. After $\mathrm{I} 20$ to $\mathrm{I} 80 \mathrm{~min}$ the sensitivity of potential transformants to penicillin decreased at least roo-fold. In similar experiments with 200 i.u. penicillin/ml (Fig. 2), a substantial fraction of penicillin-sensitive competent cells was also present. In cultures made competent by the nutritional step-down method the potential transformants were also found to be sensitive to the drug (Fig. 3).

We repeated the experiments by the method described by Nester (I964). The cultures were treated with 200 i.u. penicillin/ml at $32{ }^{\circ} \mathrm{C}$ for I h. Penicillin was destroyed by adding 400 units of penicillinase, and after 5 min incubation we added $5 \mu \mathrm{g}$ transforming DNA. DNA uptake was terminated after 10 min by 50 to $100 \mu \mathrm{g}$ DNase in the presence of $0.005 \mathrm{M}-$ magnesium sulphate. Controls were run by omitting penicillin and adding an equal volume of minimal buffer or penicillin pre-degraded by penicillinase. Table I (also Figs. I and 2) shows that when the titre of the viable cells in the culture was $>10^{8} / \mathrm{ml}$ there was no increase in transformation frequency by penicillin treatment. A substantial proportion ( 40 to $90 \%$ ) 


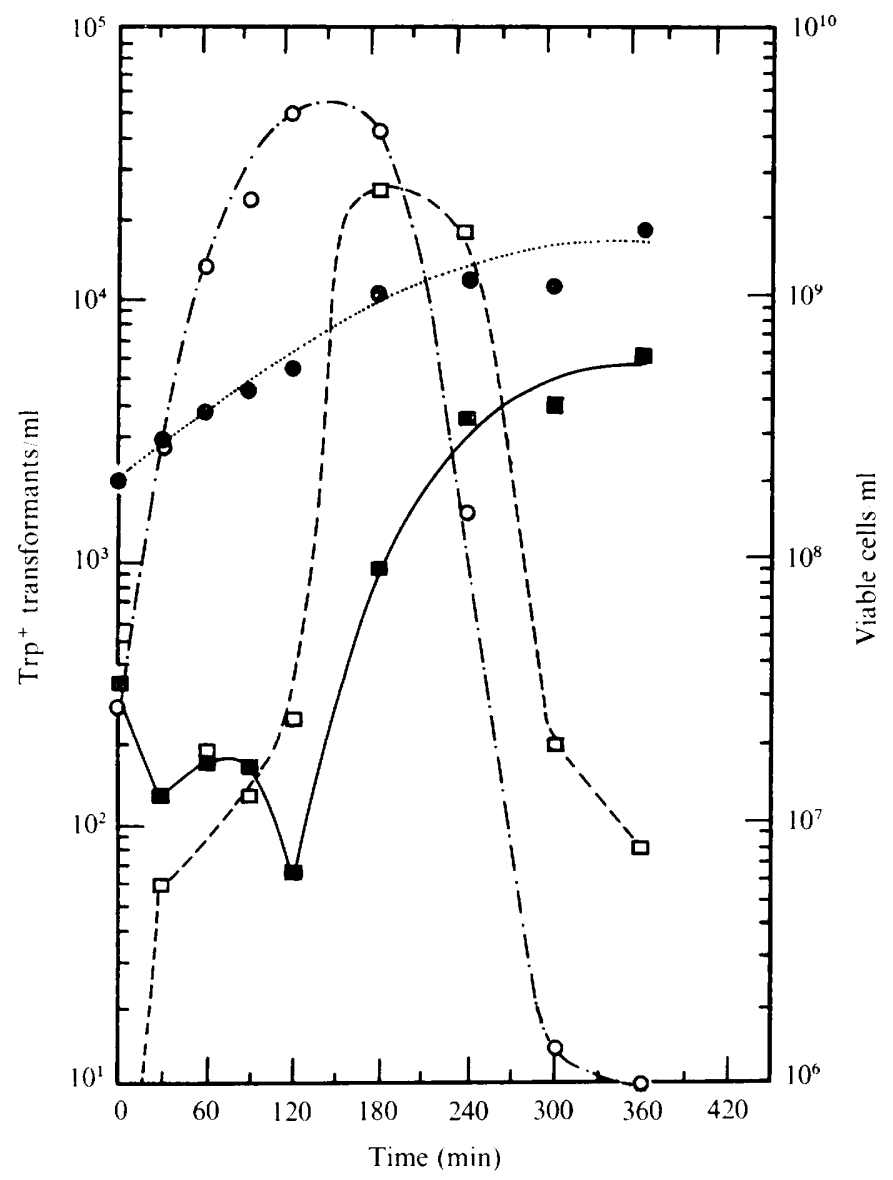

Fig. I. Action of 2000 i.u. penicillin $/ \mathrm{ml}$ on cultures made competent by the spore germination method (method 1). Two $1 \mathrm{ml}$ portions of the culture were withdrawn at the times indicated. To one portion 2000 i.u. penicillin were added and to the other a similar volume of minimal buffer. Both the cultures were incubated at $37 \mathrm{C}$ for $\mathrm{I} h$ with agitation and then transformed with $5 \mu \mathrm{g}$ (each) of B. subtilis met-II DNA (contact time $30 \mathrm{~min}$ at $37^{\circ} \mathrm{C}$ with agitation) and assayed. $\square$, Transformants $\mathrm{ml}$ (penicillin treated); $\mathbf{\square}$, viable cells $/ \mathrm{ml}$ (penicillin treated); $\bigcirc$, transformants/ $\mathrm{ml}$ (untreated); $\bullet$, viable cells $/ \mathrm{ml}$ (untreated).

of competent cells were killed in the first 90 min (Table 1). The extent of killing of the total population was either similar or less, resulting in no increase in transformation frequency by penicillin treatment. However, when the culture was diluted tenfold in medium $\mathrm{D}$ before penicillin treatment there was an increase in transformation frequency by penicillin treatment (Table 2) as reported by Nester (1964). But here also after 30 to 90 min more than $50 \%$ of the competent cells were penicillin sensitive. Table 2 and Fig. I also show that in penicillintreated cultures competence occasionally declined more slowly than in the control cultures. The explanation for this is not clear, but penicillin-sensitive competent cells were invariably observed in all the experiments during the development of competence in the cultures. 


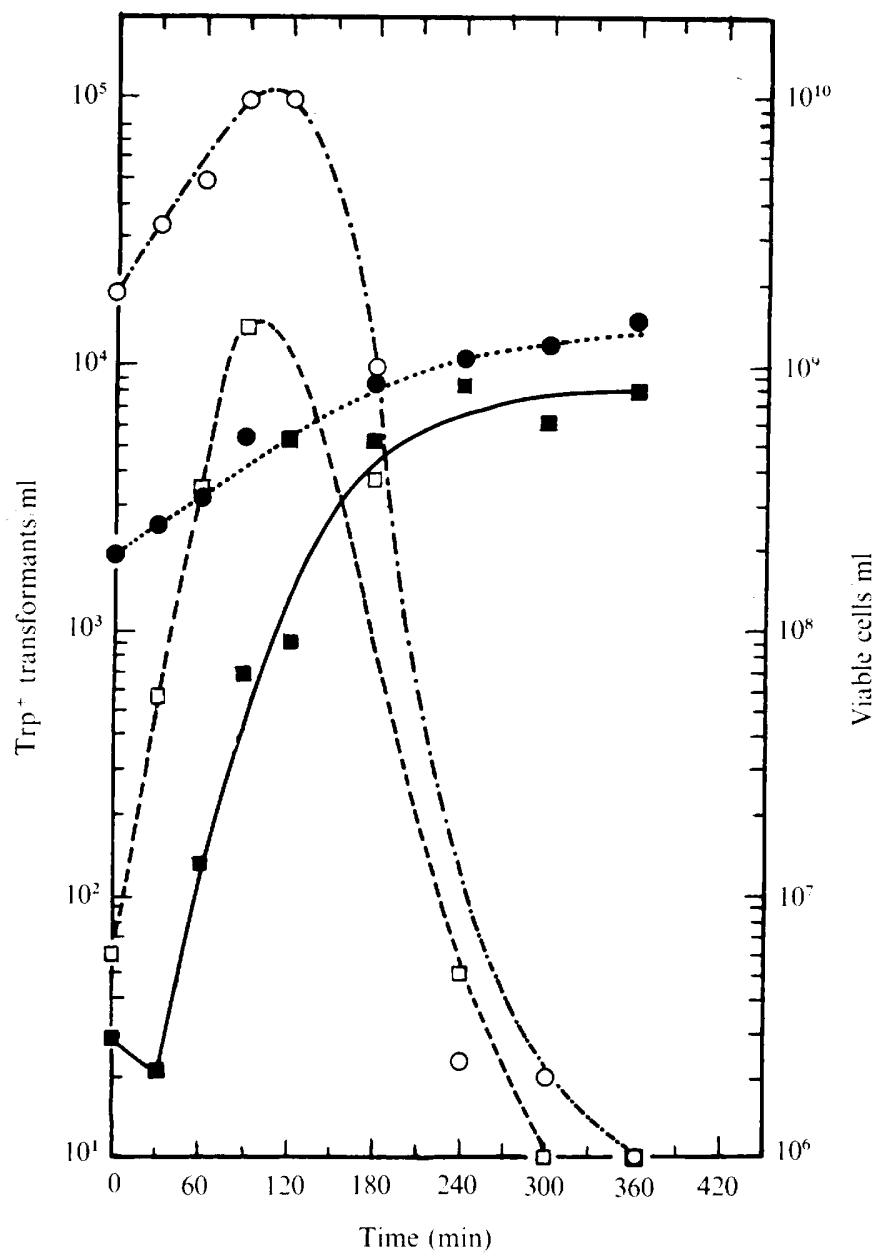

Fig. 2. Action of 200 i.u. penicillin $/ \mathrm{ml}$ on cultures made competent by the spore germination method (method 1). For experimental conditions (except penicillin concentration) and symbols see Fig. I.

Table I. Effect of penicillin treatment on competent culture at $32{ }^{\circ} \mathrm{C}$

One $\mathrm{ml}$ portions of undiluted competent culture in medium $\mathrm{D}$ at $32 \mathrm{C}$ were withdrawn at the times indicated and treated with 200 i.u. penicillin $(+$ Pen) for $\mathrm{I} \mathrm{h}$ at the same temperature with agitation. Penicillin was destroyed by incubation with 400 units of penicillinase for $5 \mathrm{~min}$. The cultures were then exposed to $5 \mu \mathrm{g} \mathrm{B}$. subtilis GSY 568 DNA for $10 \mathrm{~min}$. The uptake was terminated by 50 to $100 \mu \mathrm{g}$ DNase in the presence of $0.005 \mathrm{M}$-magnesium sulphate. In controls ( - Pen), penicillin was replaced by an equivalent amount of penicillin pre-degraded by penicillinase.

\begin{tabular}{|c|c|c|c|c|c|c|c|}
\hline \multirow{3}{*}{$\begin{array}{l}\text { Time } \\
(\min )\end{array}$} & \multirow{2}{*}{\multicolumn{2}{|c|}{$10^{\circ} \times$ Viable cells $\mathrm{ml}$}} & \multirow{2}{*}{\multicolumn{2}{|c|}{$10^{5} \times$ Transformants $\mathrm{ml}$}} & \multicolumn{2}{|c|}{$\begin{array}{c}\text { Transformation } \\
\left(\begin{array}{c}0 \\
0\end{array}\right)\end{array}$} & \multirow{3}{*}{$\begin{array}{l}\text { B A } \\
(0)\end{array}$} \\
\hline & & & & & \multirow{2}{*}{$\begin{array}{l}- \text { Pen } \\
\text { (A) }\end{array}$} & \multirow{2}{*}{$\begin{array}{c}+ \text { Pen } \\
\text { (B) }\end{array}$} & \\
\hline & - Pen & + Pen & - Pen & + Pen & & & \\
\hline 0 & $5 I \cdot I$ & $25 \cdot 2$ & $14 \cdot 2$ & $7 \cdot 6$ & 0.28 & 0.30 & 107 \\
\hline 30 & $58 \cdot 7$ & $7 \cdot 2$ & $49 \cdot 8$ & $5 \cdot 0$ & 0.85 & 0.69 & 81 \\
\hline 60 & $63 \cdot 5$ & $31 \cdot 1$ & $66 \cdot 9$ & $9 \cdot 1$ & $1 \cdot 05$ & 0.29 & 28 \\
\hline 90 & $66 \cdot 0$ & $66 \cdot 0$ & $79 \cdot 4$ & $43 \cdot 4$ & $1 \cdot 20$ & 0.66 & 55 \\
\hline 120 & $73 \cdot 0$ & $66 \cdot 6$ & $48 \cdot 3$ & $44 \cdot 9$ & 0.66 & 0.67 & 102 \\
\hline
\end{tabular}




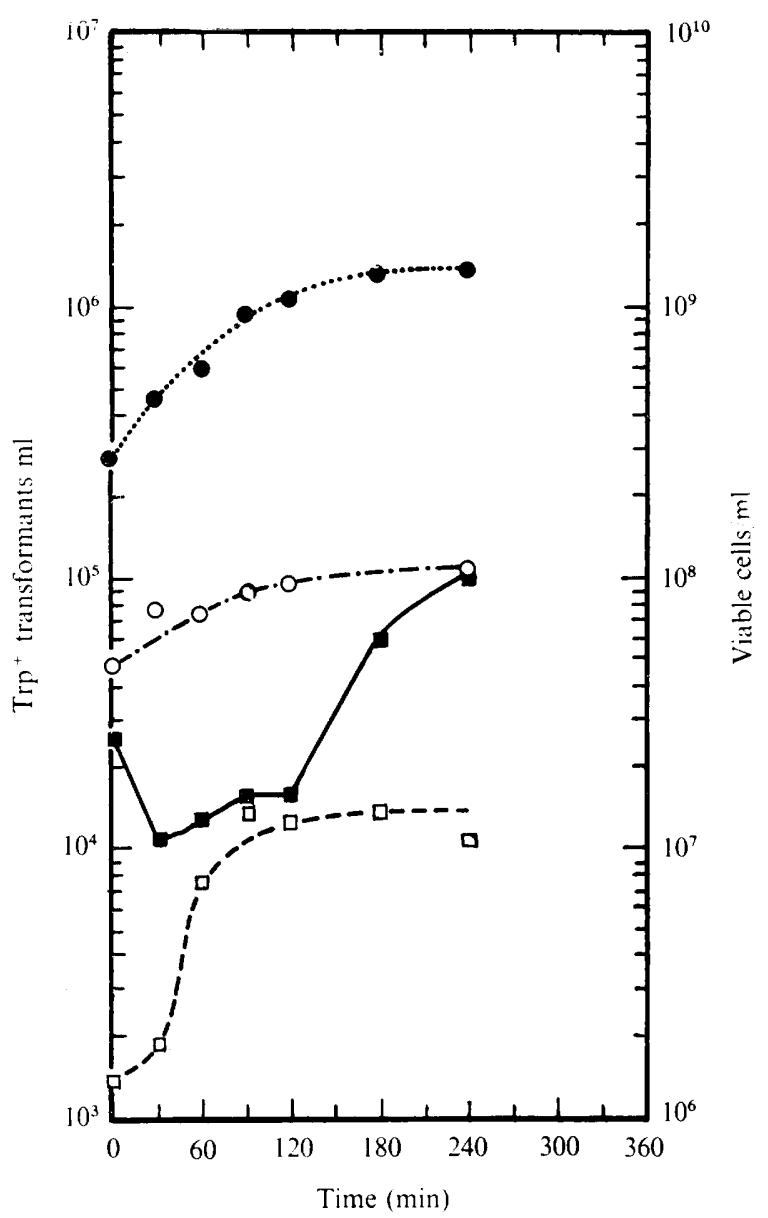

Fig. 3. Action of 2000 i.u. penicillin/ml on cultures made competent by the nutritional step-down method (method 2). For experimental conditions (apart from the method of preparing competent cells) and symbols see Fig. 1.

Table 2. Effect of penicillin treatment on tenfold diluted competent cultures at $32{ }^{\circ} \mathrm{C}$ At the indicated times $0.10 \mathrm{ml}$ portions of competent culture in medium $\mathrm{D}$ at $32{ }^{\circ} \mathrm{C}$ were diluted tenfold with medium D at $32 \mathrm{C}$ and treated with 200 i.u. penicillin ( $+\mathrm{Pen}$ ) for $\mathrm{I} h$ at the same temperature with agitation. Penicillin was destroyed by incubation with 400 units of penicillinase for $5 \mathrm{~min}$. Then the cultures were transformed with $5 \mu \mathrm{g} \mathrm{B}$. subtilis GSY 568 DNA for Io min and uptake was terminated by DNase. In controls ( - Pen), penicillin was replaced by an equivalent volume of minimal buffer.

\begin{tabular}{|c|c|c|c|c|c|c|c|}
\hline \multirow{3}{*}{$\begin{array}{l}\text { Time } \\
\text { (min) }\end{array}$} & \multirow{2}{*}{\multicolumn{2}{|c|}{$10^{-6} \times$ Viable cells $/ \mathrm{ml}$}} & \multirow{2}{*}{\multicolumn{2}{|c|}{$\mathrm{IO}^{-4} \times$ Transformants $/ \mathrm{ml}$}} & \multicolumn{2}{|c|}{$(\%)$} & \multirow{3}{*}{$\begin{array}{l}\text { B/A } \\
(\%)\end{array}$} \\
\hline & & & & & \multirow{2}{*}{$\begin{array}{l}\text {-Pen } \\
\text { A) }\end{array}$} & \multirow{2}{*}{$\begin{array}{l}+ \text { Pen } \\
\text { (B) }\end{array}$} & \\
\hline & - Pen & + Pen & - Pen & + Pen & & & \\
\hline 0 & $2 \mathrm{I} \cdot 4$ & $12 \cdot 7$ & 0.84 & 0.82 & 0.04 & 0.065 & 160 \\
\hline 30 & $33 \cdot 0$ & $5 \cdot 19$ & $7 \cdot 12$ & $1 \cdot 73$ & 0.22 & 0.33 & 150 \\
\hline 60 & $50 \cdot 4$ & $6 \cdot 25$ & 12.9 & $5 \cdot 25$ & 0.26 & 0.82 & 320 \\
\hline 90 & 67.5 & $8 \cdot 25$ & $19 \cdot 2$ & $9 \cdot 45$ & 0.28 & $1 \cdot 15$ & 410 \\
\hline 120 & $83 \cdot 5$ & $35 \cdot 7$ & $9 \cdot 10$ & 16.9 & 0.11 & 0.47 & 430 \\
\hline I 50 & 93.4 & $45 \cdot 3$ & $1 \cdot 5 \mathrm{I}$ & 6.07 & 0.016 & 0.13 & 810 \\
\hline 180 & 110 & $52 \cdot 5$ & $I \cdot 50$ & $5 \cdot 48$ & 0.014 & 0.10 & 710 \\
\hline 210 & 108 & $47 \cdot 7$ & 0.78 & $2 \cdot 0 \mathrm{I}$ & 0.007 & 0.042 & 600 \\
\hline
\end{tabular}




\section{DISCUSSION}

In analysing the results we tacitly assumed that under similar conditions a culture having a large number of competent cells would give more transformants than one having fewer competent cells. Any cell of $B$. subtilis, whether competent or non-competent, if found susceptible to the bactericidal action of penicillin was taken to be the growing cell, and the cell which was insensitive to killing by penicillin was taken to be a non-growing, non-multiplying cell (Hobby et al. 1942, cited in Nester, 1964; Nester \& Stocker, 1963).

Nester (1964) observed a several-fold decrease in the absolute number of transformants in penicillin-treated cultures. He offered two alternative explanations for this phenomenon: (i) any potentially competent or 'slightly competent' cell is killed before it becomes fully competent, (ii) penicillin prevents the synthesis of cell surface components related to DNA uptake without cell killing. In Nester's experiments, a substantial number of competent cells were not affected by penicillin treatment, whereas we observed that initially $90 \%$ or more of the competent population was sensitive to penicillin. The reason for this difference becomes clear from Figs. I and 2, which show that 90 to I 80 min may be taken for competent cells to attain insensitivity towards penicillin although these cells had already developed the capacity to take up transforming DNA and become transformed. Apparently the majority of competent cells in Nester's experiments had already stopped growing and entered a penicillin-resistant phase as a result of incubating for $90 \mathrm{~min}$ or more in CHT-IO medium (Nester, 1964). This period of 90 to $180 \mathrm{~min}$ may be utilized by the competent cells to synthesize certain macromolecules or cell structures before acquiring insensitivity to penicillin. Dooley, Hadden \& Nester (197I) reported that a cell in the process of becoming competent departs from the normal course of vegetative growth after 90 to $180 \mathrm{~min}$, and passes through a 'pre-competent' state with altered patterns of DNA, RNA and protein syntheses.

The increase in frequency of transformants upon penicillin treatment of the competent culture depends on at least two parameters: on the penicillin sensitivity of the competent cells, and on the proportion of the non-competent population killed (Tables I and 2). The smaller the competent population and the greater the non-competent population killed, the higher the increase in transformation frequency brought about by penicillin treatment is likely to be.

These studies throw light upon the temporal relationship between competence and penicillin resistance. Initially, a competent cell which is capable of taking up DNA and undergoing transformation is a growing cell susceptible to the bactericidal action of penicillin. If the growing competent cell is allowed to grow without interruption it eventually develops penicillin resistance (after 90 to $180 \mathrm{~min}$ ).

We express our gratitude to Professor O. Siddiqi for helpful suggestions.

\section{REFERENCES}

Anagnostopoulos, C. \& Spizizen, J. (196I). Requirements for transformation in Bacillus subtilis. Journal of Bacteriology 81, 74I-746.

Dooley, D. C., Hadden, C. T. \& Nester, E. W. (1971). Macromolecular synthesis in Bacillus subtilis during development of the competent state. Journal of Bacteriology 108, 668-679.

Ephrati-Elizur, E. (1965). Development of competence for transformation experiments in an overnight culture of germinating spores of Bacillus subtilis. Journal of Bacteriology 9o, 550-55I. 
GANeSAN, A. T. \& LederberG, J. (1964). Physical and biological studies on transforming DNA. Journal of Molecular Biology 9, 683-695.

Hobby, G. L., Meyer, K. \& Chaffee, E. (1942). Observations on the mechanism of action of penicillin. Proceedings of the Society for Experimental Biology and Medicine 5o, 28 [-285.

MARMUR, J. (I96I). A procedure for the isolation of deoxyribonucleic acid from micro-organisms. Journal of Molecular Biology 3, 208-2 I 8.

Nester, E. W. (1964). Penicillin resistance of competent cells in deoxyribonucleic acid transformation of Bacillus subtilis. Journal of Bacteriology 87, 867-875.

Nester, E. W., Schafer, M. \& Lederberg, J. (I963). Gene linkage in DNA transfer: a cluster of genes concerned with aromatic biosynthesis in Bacillus subtilis. Genetics 48, 529-55I.

Nester, E. W. \& STOCKER, B. A. D. (I963). Biosynthetic latency in early stages of deoxyribonucleic acid transformation in Bacillus subtilis. Journal of Bacteriology 86, 785-796.

SidDiQI, O. \& Fox, M. S. (1973). Integration of donor DNA in bacterial conjugation. Journal of Molecular Biology 77, IOI-I 23.

SPIZIZEN, J. ( 1958 ). Transformation of biochemically deficient strains of Bacillus subtilis by deoxyribonucleate. Proceedings of the National Academy of Sciences of the United States of America 44, 1072-1078.

STOCKER, B. A. D. (1963). Transformation of Bacillus subtilis to motility and prototrophy: micromanipulative isolation of bacteria of transformed phenotype. Journal of Bacteriology 86, 797-804.

Tomasz, A. (1969). Some aspects of the competent state in genetic transformation. Annual Review of Genetics $3,217-232$.

Young, F. E. \& Spizizen, J. (I961). Physiological and genetic factors affecting transformation of Bacillus subtilis. Journal of Bacteriology 81, 823-829. 